\title{
[퓌PSSCR
}

\section{Pengaruh Kombinasi Polimer Hidroksipropilmetilselulosa dan Natrium Karboksimetilselulosa terhadap Sifat Fisik Sediaan Matrix-based Patch Ibuprofen}

\author{
Dian E.Ermawati ${ }^{12^{*}}$ dan Heni Utami Prilantari ${ }^{1}$ \\ 1 Program Studi D3 Farmasi, Fakultas Matematika dan Ilmu Pengetahuan Alam, Universitas Sebelas Maret \\ 2 Grup Riset Farmasi Terapan, Universitas Sebelas Maret \\ *email korespondensi : dianekae@ staff.uns.ac.id
}

\begin{abstract}
Abstrak: Ibuprofen merupakan obat non-steroidal anti inflamantory derivat asam propionat yang mempunyai aktivitas antiinflamasi, analgesik dan antipiretik. Ibuprofen dibuat dalam bentuk sediaan transdermal patch untuk menghindari efek samping iritasi gastrointestinal dan first pass effect di hati pada penggunaan peroral. Komponen utama pada sediaan patch adalah polimer. Polimer menetukan dan mengontrol release zat aktif dari sediaan. Penelitian ini bertujuan untuk mengetahui pengaruh kombinasi polimer hidroksi propil metil selulosa (HPMC) dan carboxymethyl cellulose natrium (CMC-Na) terhadap sifat fisik sediaan matriks patch ibuprofen. Sediaan matriks patch ibuprofen dibuat dalam tiga formula dengan perbandingan polimer HPMC: CMC-Na yaitu 3:1, 1:1, dan 1:3. Analisa data dilakukan menggunakan uji One Way ANOVA untuk mengetahui perbedaan sifat fisik dari ketiga formula selama 4 minggu, dilanjutkan dengan uji post hoc untuk mengetahui formula yang memberikan perbedaan signifikan. Hasil analisa menunjukkan bahwa perbedaan konsentrasi polimer HPMC dan CMC-Na dalam sediaan matriks patch ibuprofen memberikan pengaruh signifikan terhadap sifat fisik sediaan patch meliputi ketebalan, bobot patch dan kandungan lembab $(p<0,05)$. Konsentrasi optimum kombinasi HPMC dan CMC-Na sebagai polimer dalam sediaan matriks patch ibuprofen adalah dengan perbandingan (3:1) karena memiliki kelenturan, ketebalan, nilai $\mathrm{pH}$ dan kandungan lembab yang sesuai dengan persyaratan matriks patch yang baik.
\end{abstract}

Kata kunci: Ibuprofen; Patch; HPMC; CMC-Na

\begin{abstract}
The Influence of Polymers Combination Between Hydroxy Propyl Methyl Cellulose and Sodium Carboxymethylcellulose on The Physical Properties of Ibuprofen Matrix-Based Patch Formulation. Ibuprofen is a propionic acid derivative, non-steroidal anti-inflammatory drug which has anti-inflammatory, analgesic and antipyretic activity. In order to avoid side effects of gastrointestinal irritation and first pass effect in the liver regarding the oral delivery system, ibuprofen was formulated into transdermal formulation. Polymers is the most important components in a patch transdermal formulation. In addition, the polymer governs and controls the drug release. This study aimed to determine the effect of the combination of hydroxy propyl methyl cellulose (HPMC) and sodium carboxymethyl cellulose $(\mathrm{CMC}-\mathrm{Na})$ polymers on the physical properties of the ibuprofen matrix-based patch formulation. The ibuprofen matrix-based patch formulation was prepared in three formula along with different HPMC to CMC-Na ratio e.g. 3:1; 1:1, and 1:3. Statistical analysis namely One Way ANOVA was applied to analyze the obtained data and followed by the post hoc test to find out significant difference between formula. The results showed that different HPMC to CMC-Na ratio incorporated into the ibuprofen matrix-based patch formulation had a
\end{abstract}


significant effect on the physical properties namely thickness, patch weight and moisture content $(\mathrm{p}<0.05)$. The optimum concentration of HPMC to CMC-Na ratio as a polymer in the ibuprofen matrix-based formulation was 3:1. Therefore, it produced better flexibility, thickness, $\mathrm{pH}$ and moisture content values which fulfilled the requirement of patch formulation characteristics.

Keywords: Ibuprofen, Patch, HPMC, CMC-Na

\section{Pendahuluan}

Ibuprofen merupakan obat non-steroidal anti inflamantory (NSAID) yang mempunyai aktivitas antiinflamasi, analgesic, dan antipiretik. Ibuprofen merupakan turunan asam propionat yang merupakan obat NSAID poten dan biasa digunakan untuk mengobati kondisi arthritis akut dan kronik (Rasool et al., 2010). Mekanisme aksi Ibuprofen adalah menghambat isoenzim cyclooxygenanase-1 dan cyclooxygenase-2 dengan cara mengganggu perubahan asam arakidonat menjadi prostaglandin. Efek samping ibuprofen dalam penggunaan rute peroral diantaranya dapat menyebabkan diare, mual, muntah, sakit kepala, nyeri abdomen, perdarahan lambung, dan efek samping tersebut dapat meningkat apabila digunakan secara berulang (BPOM RI, 2019). Sediaan lokal mampu memberikan efek langsung di tempat aksi, salah satu cara mengurangi efek samping ibuprofen pada saluran cerna. Transdermal patch adalah salah satu sediaan lokal yang dapat menghantarkan obat ke tempat aksi. Sistem penghantaran obat secara transdermal merupakan inovasi dalam sistem penghantaran obat untuk mengurangi problem bioavailabilitas obat melalui jalur oral dan parenteral. Sistem penghantaran obat secara transdermal dalam pemberian obat melewati kulit cenderung mengalami peningkatan baik untuk efek terapetik lokal pada kulit yang sakit (penghantaran obat topikal) maupun penghantaran obat sistemik (Prajapati et al., 2011).

Sistem penghantaran obat secara transdermal mempunyai banyak keuntungan yaitu memberikan pelepasan obat yang konstan, mudah digunakan, mengurangi frekuensi pemberian obat, mengeliminasi first-pass metabolism, serta mengurangi efek samping seperti iritasi lambung dan meningkatkan kepatuhan pasien (Kumar et al., 2013). Penelitian ini dibuat sediaan patch bentuk matriks karena pada patch matriks tidak terjadi kebocoran membran sehingga tidak terjadi pelepasan obat dalam jumlah besar serta dapat membentuk sediaan patch yang tipis, lentur dan elegan sehingga nyaman untuk digunakan (Arunachalam et al., 2010). Bahan obat yang dapat diformulasikan menjadi bentuk sediaan transdermal harus memenuhi persyaratan diantaranya bahan obat harus memiliki bobot molekul yang kecil (<500 Da) (Gaikwad, 2013), memiliki nilai koefisien partisi oktanol/air (log P) antara 1-4, waktu paruh $\left(\mathrm{t} \frac{1}{2} 2\right)<10$ jam, bioavailabilitas obat secara oral rendah dan obat tidak mengiritasi kulit (Yadav et al., 2012). Sifat fisika kimia ibuprofen yakni memiliki koefisien partisi (log P) 
3,6 (Kumar et al., 2011), memiliki berat molekul rendah yaitu 206,28 g/mol dan memiliki waktu (Nirja et al., 2013). Berdasarkan karakteristik tersebut maka ibuprofen $200 \mathrm{mg}$ merupakan kandidat yang mampu dikembangkan menjadi bentuk sediaan transdermal patch.

Polimer merupakan komponen utama dalam sediaan transdermal patch. Polimer menentukan dan mengontrol kecepatan pelepasan obat dari sediaan (Arunachalam et al., 2010). Polimer yang digunakan sebagai pembawa ada dua jenis, yaitu polimer hidrofilik dan polimer hidrofobik (Rowe et al., 2009). Kombinasi polimer hidrofilik dalam pembuatan patch memberikan pelepasan obat yang lebih cepat dibanding kombinasi polimer-polimer hidrofilik. Berdasarkan parameter fisikokimia dan uji pelepasan in vitro sediaan patch, formula dengan HPMC dan CMC-Na merupakan formula paling baik dibanding kombinasi polimer hidrofilik dan lipofilik, polivinilpirolidon (PVP) dan eksipien koproses dan PVP: Polivinilalkohol (PVA). Penggunaan polimer hidrofilik dapat meningkatkan permeabilitas matrik, sehingga difusi obat melalui matriks lebih cepat dibandingkan polimer hidrofobik (Kandavilli et al., 2002; Valenta dan Auner, 2004). HPMC mampu mengembang lebih baik dibanding polimer lain sehingga mampu melepaskan obat dari matriks relatif cepat. Penelitian Kurniawati (2016) pada formulasi matriks patch ekstrak bunga rosela dengan kombinasi polimer HPMC dan CMC-Na menunjukkan bahwa formula optimum yang didapat memiliki konsentrasi CMC-Na lebih sedikit dari HPMC. Pada penelitian ini akan mengkombinasikan polimer hidrofilik untuk mendapatkan proporsi konsentrasi masing-masing polimer yang terbaik untuk sediaan patch ibuprofen berdasarkan sifat fisik dan kemampuan pelepasan zat aktifnya.

\section{Bahan dan Metode}

Bahan : Ibuprofen (Global Chemindo, Megatrading), HPMC type cosmestics (Hercules), CMC-Na (Changshu), PEG 400 (DOW Chemical Singapore), Nipagin (China), Etanol 96\% (Brataco) dan Aquadest.

Alat : timbangan analitik (Precisa-xb, Switzerland), penangas air (MASPION S-302, Indonesia), jangka sorong (Tricle Brand, Sanghai China), spektrofotometer (Thermo Genesys 10S Uv-Vis; Whaltam, US), pH meter starter 300 (OHAUS New Jersey US), moisture content analyzer (OHAUS, New Jersey US)

\subsection{Formulasi matriks patch ibuprofen}

Formula matriks patch dibuat dengan tiga variasi perbedaan konsentrasi HPMC dan CMC-Na sebagai polimer (Tabel 1). Formula yang digunakan merupakan modifikasi dari formula pada penelitian yang dilakukan oleh Darwekhar et al. (2011). Dosis oral yang biasa digunakan untuk mengatasi nyeri dan demam pada anak usia 3-7 tahun adalah 100-125 mg 34 kali sehari (BPOM RI, 2019). Berdasarkan hasil penelitian yang dilakukan oleh Predel et al. 
(2018), dengan penggunaan $200 \mathrm{mg}$ ibuprofen pada plester terbukti efektif dan aman digunakan untuk pengobatan rasa sakit akibat cedera jaringan lunak traumatis akut terkait olahraga pada orang dewasa.

Tabel 1. Formula matriks patch ibuprofen dengan modifikasi (Darwekhar et al., 2011). Keterangan: konsentrasi HPMC: CMC-Na (3:1) (Formula 1); konsentrasi HPMC: CMC-Na (1:1) (Formula 2); konsentrasi HPMC: CMC-Na (1:3) (formula 3)

\begin{tabular}{llccc}
\hline \multicolumn{1}{c}{ Bahan } & \multicolumn{1}{c}{ Fungsi } & $\begin{array}{c}\text { Formula 1 } \\
\text { (gram) }\end{array}$ & $\begin{array}{c}\text { Formula 2 } \\
(\text { gram })\end{array}$ & $\begin{array}{c}\text { Formula 3 } \\
\text { (gram) }\end{array}$ \\
\hline Ibuprofen & Bahan aktif & 0,1 & 0,1 & 0,1 \\
HPMC & Polimer hidrofilik & 0,3 & 0,2 & 0,1 \\
Na-CMC & Polimer hidrofilik & 0,1 & 0,2 & 0,3 \\
Nipagin & Pengawet & 0,005 & 0,005 & 0,005 \\
PEG 400 & Plasticizer dan & 0,4 & 0,4 & 0,4 \\
& penetration enhancer & & & 5 \\
Etanol 96\% & Pelarut & 5 & 5 & Ad 15 \\
Aquadest & Pelarut & Ad 15 & Ad 15 & Ad \\
\hline
\end{tabular}

\subsection{Pembuatan matriks patch ibuprofen}

Sediaan matriks patch dibuat dengan menggunakan teknik solvent casting. Ibuprofen dilarutkan dalam campuran etanol dan PEG 400. Larutan ibuprofen selanjutnya dimasukkan ke dalam campuran polimer HPMC dan CMC-Na yang sebelumnya sudah dikembangkan dalam aquadest kemudian diaduk sampai homogen. Nipagin yang sebelumnya sudah dilarutkan dengan etanol kemudian ditambahkan ke dalam campuran dan diaduk hingga homogen. Campuran lalu dituang ke dalam cetakan cawan petri dan pelarut dibiarkan menguap pada suhu kamar selama 3 hari (3x24 jam). Patch yang telah kering kemudian dikeluarkan dari cetakan (Darwekhar et al., 2011).

\subsection{Evaluasi sediaan matriks patch ibuprofen}

Evaluasi sifat fisik patch meliputi uji organoleptis, uji bobot, uji ketebalan patch, uji ketahanan terhadap lipatan, pH permukaan, moisture content (kandungan lembab) serta kadar obat dalam sediaan. Pemeriksaan organoleptis meliputi pengamatan warna, bau dan kondisi permukaan dari patch yang dihasilkan (Rahim et al., 2016). Pengujian bobot patch dapat dilakukan dengan menimbang matriks satu persatu menggunakan neraca elektrik (Pudyastuti et al., 2014). Sediaan matriks patch yang semakin ringan maka semakin nyaman untuk digunakan (Kurniawati, 2016).

Pengujian ketebalan patch diukur pada tiga titik berbeda dengan menggunakan jangka sorong (Puspitasari et al., 2016). Matriks patch yang semakin tebal kurang disukai oleh penggunanya sebab dirasakan kurang nyaman digunakan (Indrati dan Nugroho, 2012). Sediaan matriks patch yang terlalu tebal akan mempersulit lepasnya zat aktif dari patch (Arifin et al., 2019). Pengujian pH permukaan dilakukan untuk menjamin $\mathrm{pH}$ permukaan 
patch sesuai dengan $\mathrm{pH}$ kulit. Pengujian ini dilakukan dengan melarutkan patch pada $5 \mathrm{~mL}$ aquadest bebas $\mathrm{CO}_{2}$ dan diuji menggunakan $\mathrm{pH}$ meter. Kriteria rentang $\mathrm{pH}$ yang dapat diterima agar tidak mengiritasi kulit yaitu 4-8 (Tranggono dan Latifah, 2007).

Pengujian ketahanan terhadap pelipatan dilakukan dengan melipat matriks berkali-kali pada posisi yang sama. Jumlah pelipatan menunjukkan nilai ketahanan matriks terhadap pelipatan sampai patah (Pudyastuti et al., 2014). Sediaan patch dikatakan baik apabila memiliki nilai ketahanan lipat lebih dari 300 kali (Jhawat et al., 2013). Pengujian moisture content (kandungan lembab) bertujuan untuk mengetahui kandungan lembab dalam sediaan patch yang dapat mempengaruhi stabilitas dari sediaan (Kumar et al., 2013). Kandungan lembab yang terlalu rendah akan menyebabkan patch mudah rapuh namun bila kandungan lembab terlalu tinggi maka pertumbuhan bakteri tak bisa dihindari (Mukherjee et al., 2005). Uji ini dilakukan dengan menggunakan alat moisture analyzer pada suhu $105^{\circ} \mathrm{C}$ (Puspitasari et al., 2016).

Pengujian kadar ibuprofen dilakukan untuk mengetahui kadar ibuprofen dalam sediaan matriks patch telah memenuhi persyaratan atau belum. Pada tahap awal penetapan kadar zat aktif adalah dengan melakukan penentuan panjang gelombang maksimum ibuprofen. Pengukuran panjang gelombang maksimum dilakukan dengan cara scanning pada panjang gelombang 200-400 nm. Rentang panjang gelombang tersebut didapatkan nilai absorbansi yang paling tinggi. Panjang gelombang maksimum ibuprofen menurut literature yaitu $221 \mathrm{~nm}$ (DepKes RI, 2014), selanjutnya dilakukan penetapan kurva baku ibuprofen dalam etanol 96\%. Patch yang telah disiapkan diukur serapannya pada panjang gelombang maksimum ibuprofen. Hasil absorbansi yang didapatkan selanjutnya dimasukkan dalam persamaan regresi linier. Persyaratan kadar zat aktif ibuprofen dalam sediaan tidak boleh kurang dari $80 \%$ dan tidak lebih dari 110\% menurut Farmakope Indonesia Edisi V (DepKes RI, 2014).

\subsection{Analisa data}

Analisa statistika menggunakan software SPSS dengan uji Shapiro-Wilk, data terdistribusi normal dengan uji One-Way ANOVA untuk mengetahui signifikansi data yang diperoleh pada masing-masing parameter, dilanjutkan dengan uji Post Hoc untuk mengetahui formula yang menunjukkan hasil berbeda signifikan. Analisa statistika paired sample t-test untuk membandingkan signifikansi data pada hari ke-0 dan hari ke-28.

\section{Hasil dan Pembahasan}

Pembuatan matriks patch menggunakan metode solvent casting karena sesuai dengan jumlah bahan yang digunakan yaitu skala laboratorium. Solvent casing adalah teknik pencetakan film dimana setiap komponen bahan dalam formula dilarutkan kemudian 
dicampur dan dicetak pada suhu tertentu. Matriks patch ibuprofen yang dihasilkan formula 1, 2, dan 3 menunjukkan tidak ada perubahan selama 4 minggu penyimpanan yaitu memiliki tampilan warna patch yang putih, lentur, permukaan yang halus dan lembab serta berbau khas senyawa aktif obat. Hal ini diharapkan dapat meningkatkan kenyamanan selama pemakaian dan relatif tidak mengganggu aktivitas pasien, terutama keterimaan pasien. Makroskopis sediaan matriks patch yang diperoleh tersaji pada Gambar 1. Perbedaan rasio polimer yang digunakan secara visual menyebabkan perbedaan kehalusan dan rigiditas dari patch yang terbentuk.
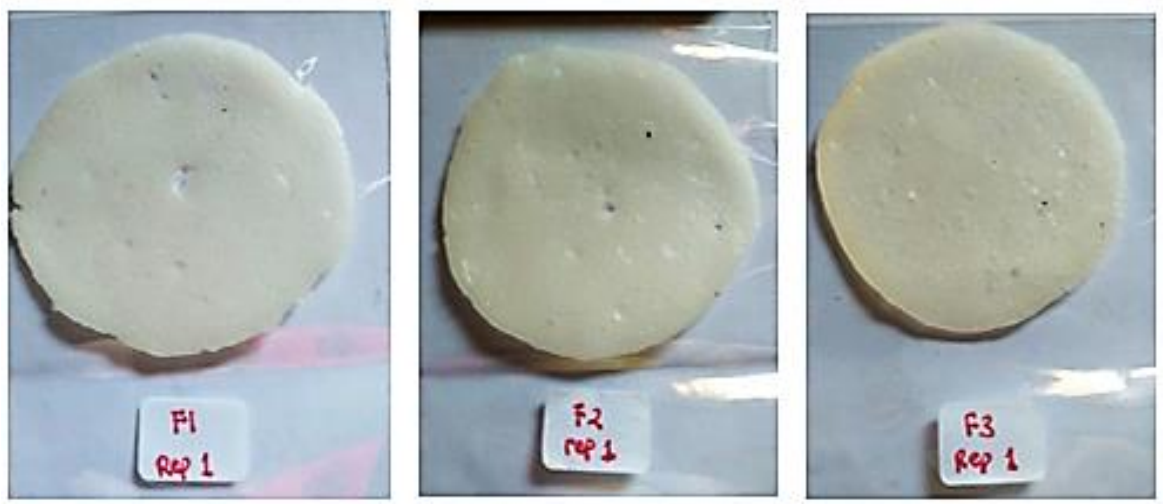

Gambar 1. Sediaan matriks patch Ibuprofen Formula optimum dengan variasi komposisi HPMC dan CMC-Na (3:1)

Hasil uji ketahanan pelipatan terhadap formula 1 dan 2 menghasilkan ketahanan lipatan yang sama yaitu lebih dari 300 lipatan, sedangkan, pada formula 3 menghasilkan ketahanan lipat <300 lipatan hal ini disebabkan karena pada formula 3 memiliki kelembapan lebih tinggi dibandingkan formula 1 dan 2 sehingga menyebabkan patch menjadi mudah robek. Kandungan air dalam suatu polimer akan mempengaruhi sifat elastisitas dari suatu polimer. Semakin elastis suatu polimer, maka akan semakin tahan terhadap lipatan. Hasil pengujian terhadap bobot sediaan matriks patch (Gambar 2a), menunjukkan bahwa terjadi peningkatan bobot matriks patch antara formula 1, 2, dan 3. Peningkatan bobot pada matriks patch disebabkan karena komponen CMC-Na signifikan dalam meningkatkan bobot matriks patch dibanding komponen HPMC karena sifat CMC-Na mampu meretensi air dan menjebak air dalam struktur polimer yang mengembang sehingga menyebabkan CMC-Na mampu meningkatkan bobot matriks patch (Rowe et al., 2009). Air akan tertahan di dalam patch selama proses pengeringan pada waktu pembuatan matriks patch yang akan berdampak pada peningkatan bobot matriks patch ibuprofen yang dihasilkan (Kurniawati, 2016).

Hasil pengujian terhadap ketebalan sediaan matriks patch menunjukkan bahwa terjadi peningkatan ketebalan matriks patch antara formula 1, 2, dan 3 (Gambar 2b). Hasil ketebalan matriks berbanding lurus dengan bobot matriks. Peningkatan bobot matriks akan 
menyebabkan peningkatan ketebalan matriks. Peningkatan ketebalan pada matriks patch disebabkan karena komponen CMC-Na signifikan dalam meningkatkan ketebalan matriks patch dibanding komponen HPMC karena sifat CMC-Na memiliki kapasitas swelling yang dominan sehingga menyebabkan CMC-Na mampu meningkatkan ketebalan matriks patch (Rowe et al., 2009). Ketika proses swelling, air akan tertahan di dalam patch selama proses pengeringan pada waktu pembuatan matriks patch yang akan berdampak pada peningkatan bobot dan ketebalan matriks patch ibuprofen yang dihasilkan (Kurniawati, 2016).

Hasil pengujian terhadap moisture content sediaan matriks patch menunjukkan bahwa terjadi peningkatan kadar moisture content pada matriks patch antara formula 1, 2, dan 3 (Gambar 2c). Peningkatan kadar moisture content pada matriks patch disebabkan karena komponen CMC-Na signifikan dalam meningkatkan kadar moisture content pada matriks patch dibanding komponen HPMC karena sifat CMC-Na yang berinteraksi dengan molekul air melalui ikatan hidrogen sehingga air akan teretensi dan menyebabkan CMC-Na mampu meningkatkan kadar moisture content pada matriks patch (Rowe et al., 2009). Air yang tertahan di dalam patch (polimer yang mengembang) memiliki karakteristik yang berbeda dengan air adsorpsi sehingga tidak hilang selama proses pengeringan pada waktu pembuatan matriks patch. Fenomena tersebut berdampak pada peningkatan kadar moisture content pada matriks patch ibuprofen yang dihasilkan (Kurniawati, 2016).

Hasil pengujian terhadap pH (Gambar 2d) sediaan matriks patch menunjukkan bahwa sediaan matriks patch formula 1, 2 dan 3 memiliki pH yang aman untuk penggunaan topikal karena memiliki pH antara 4-8 (Tranggono dan Latifah, 2007). Perubahan nilai pH dapat dipengaruhi oleh media yang terdekomposisi oleh suhu saat pembuatan atau penyimpanan yang menghasilkan asam atau basa. HPMC dan CMC-Na cenderung bersifat asam sehingga mempengaruhi $\mathrm{pH}$ Ibuprofen dalam sediaan. Perubahan $\mathrm{pH}$ juga disebabkan oleh faktor penyimpanan yang hanya mengontrol suhu tanpa kelembaban, kombinasi bahan yang kurang stabil dalam sediaan karena teroksidasi (Young dan Anne, 2002). Formula 1 dengan perbandingan komposisi HPMC:CMC-Na (3:1) dipilih sebagai formula yang memenuhi persyaratan fisik sediaan patch dalam kurun waktu pengamatan selama 28 hari. 

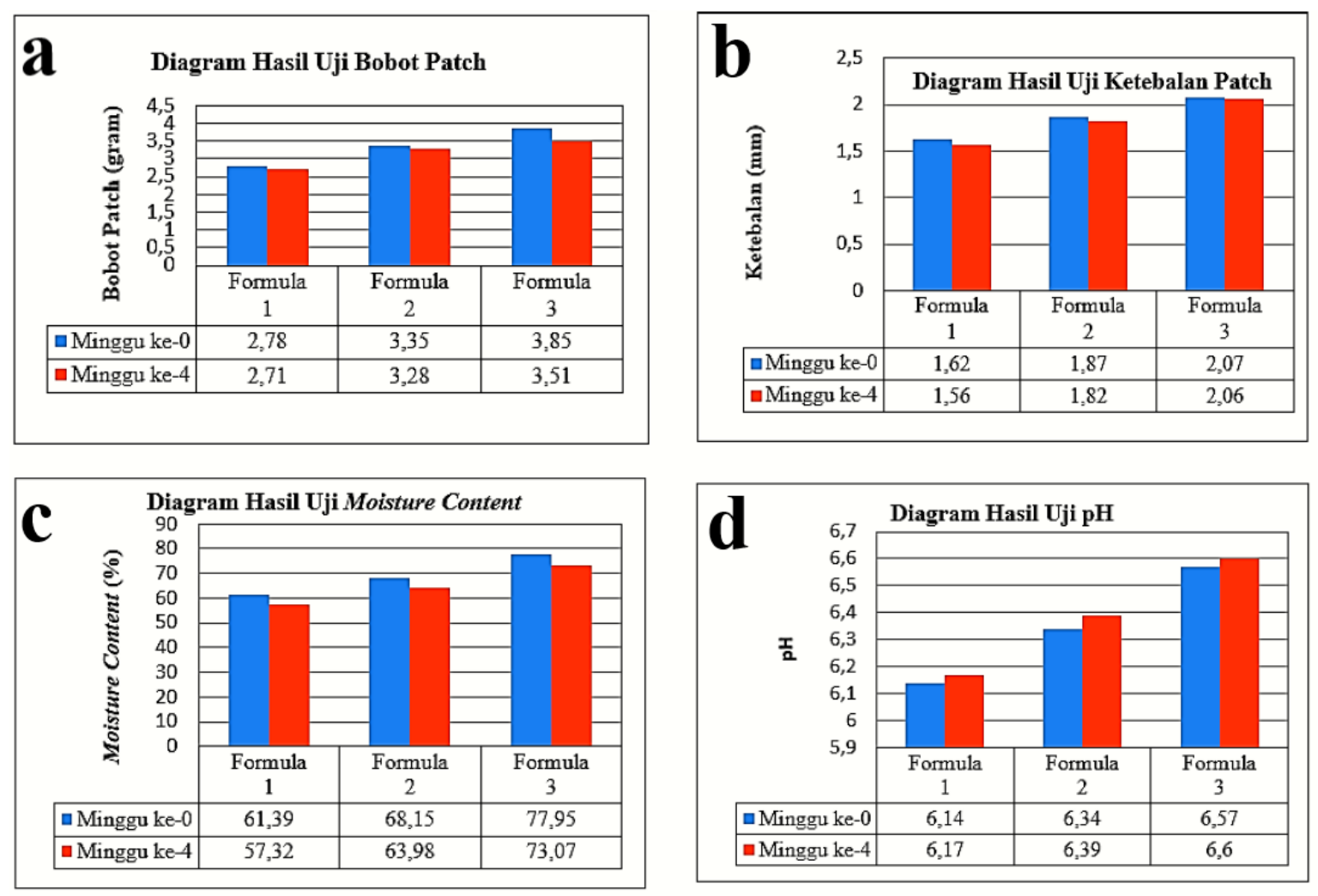

Gambar 2. Hasil pemeriksaan bobot (a), ketebalan (b), moisture content (c), dan pH (d) sediaan patch ibuprofen dengan variasi komposisi HPMC dan CMC-Na selama empat minggu penyimpanan.

Hasil scanning panjang gelombang maksimal ibuprofen dalam larutan etanol $96 \%$ adalah $222 \mathrm{~nm}$. Hasil penetapan kadar zat aktif formula patch terpilih yaitu formula 1 diperoleh kadar ibuprofen matriks patch ibuprofen yaitu sebesar 102,20\% pada pengujian minggu ke-0 dan sebesar 94,09\% pada pengujian minggu ke-4. Penurunan kadar zat aktif selama penyimpanan dikarenakan polimer yang digunakan adalah polimer hidrofilik sehingga dapat mempengaruhi $\mathrm{pH}$ sediaan, namun demikian kadar zat aktif ibuprofen dalam matriks patch masih memenuhi persyaratan. Persyaratan kadar zat aktif ibuprofen dalam sediaan tidak kurang dari $80 \%$ dan tidak lebih dari 110\% (Huber dan Ludwig, 2007). Hasil yang diperoleh menunjukan bahwa kadar zat aktif ibuprofen dalam sediaan matriks patch telah memenuhi persyaratan bahasan harus menjelaskan dan menekankan penjelasan hasil yang diperoleh, tidak lagi mengulangi hasil. Pembahasan harus dapat menjawab dan menganalisa keterkaitan hasil dengan tujuan penelitian dan hasil penelitian sebelumnya, baik jika hasil sama maupun berbeda dengan penelitian sebelumnya.

\section{Kesimpulan}

Penambahan CMC-Na berpengaruh signifikan terhadap sifat fisik sediaan matriks patch ibuprofen yaitu dapat menaikkan ketebalan, bobot patch dan moisture content. Formula 
optimal dihasilkan oleh formula dengan perbandingan HPMC dan CMC-Na (3:1) karena berdasarkan hasil pengujian terhadap sifat fisik formula 1 memiliki daya tahan lipat $>300$ kali, $\mathrm{pH}$ (4-8), memiliki ketebalan dan bobot patch yang lebih rendah dari formula 2 dan 3 serta memiliki \% moisture content yang mendekati dengan sediaan patch yang ada dipasaran (tidak terlalu lembab dan tidak terlalu kering). Formula paling optimal patch ibuprofen diharapkan mampu melepaskan ibuprofen secara terkontrol dan mampu memberikan efektifitas sebagai analgesik.

\section{Daftar Pustaka}

Arifin, A., Sartini dan Martianti. (2019). Evaluasi Karakteristik Fisik dan Uji Permeasi pada Formula Patch Aspirin menggunakan Kombinasi Etil Selulosa dengan Polivinilpirolidon. Jurnal Sains dan Kesehatan, 2(1), pp. 40-49.

Arunachalam, A., Karthikeyan, M., Kumar, D., Prathap, M., Sethuraman, S. dan Ashutoshkumar, S. (2010). Transdermal drug delivery system: a review, International Journal of Pharmaceutical Science and Research, 1(1), pp. 70-81.

BPOM RI. (2019). Pusat Informasi Obat Nasional, Badan Pengawas Obat dan Makanan, Jakarta.

Darwekhar, G., Jain, D.K. dan Patidar, V.K. (2011). Formulation and Evaluation of Transdermal Drug Delivery System of Clopidogrel Bisulfate. Asian Journal of Pharmacy and Life Science, 1(3), pp. 269-278.

Depkes RI. (2014). Farmakope Indonesia Edisi Kelima, Departemen Kesehatan Republik Indonesia: Jakarta.

Gaikwad, A.K. (2013). Transdermal Drug Delivery System: Formulation Aspects and Evaluation. Journal of Pharmaceutical Science, 1(1), pp. 1-10.

Huber dan Ludwig. (2007). Validation and Qualification in Analitical Laboratories Second Edition. New York: Informa USA Inc.

Indrati O. dan Nugroho A. (2012). Pengaruh asam oleat, propilen glikol dan isopropil alkohol pada formula patch transdermal kalium losartan dengan matriks hidroksipropil metilselulosa dan etil selulosa. Disertasi. Yogyakarta: Fakultas Farmasi Universitas Gadjah Mada.

Jhawat, Saini, Kamboj dan Maggon. (2013). Transdermal Drug Delivery System: Approaches and Advancements in Drug Absorption Through Skin. International Journal of Pharmaceutical Sciences Review and Research, 20 (1), pp. 47-56.

Kandavilli, S., Nair, V. dan Panchagnula, R. (2002). Polymers in Transdermal Drug Delivery Systems. Pharmaceutical Technology, 26 (5), pp. 62-81.

Kumar, Sairam, Anandbabu, Karpagavalli, Maheswaran, dan Narayanan. (2011). Formulation and Evaluation of Transdermal Patches of Salbutamol. Research Journal of Pharmaceutical, Biological and Chemical Sciences, 3(3), pp.1132-1139. 
Kumar, S.V., Turun, P. dan Kumar T.A. (2013). Transdermal drug delivery system for nonsteroidal anti-inflammatory drugs: A review, Indo American Journal of Pharmaceutical Research, 3(5), pp. 3588-3605.

Kurniawati, I., Kharis, A., Setyawati, E. (2016). Formulasi Matriks Patch Ekstrak Bunga Rosela (Hibiscus Sabdariffa L.) dan Aktivitasnya terhadap Sel Pre Adiposa 3t3-L1. Tesis, Fakultas Farmasi. Universitas Gadjah Mada : Yogyakarta.

Mukherjee, B., Kanupriya, M.S., Das, S. dan Patra B. (2005). Sorbitan monolaurate 20 as a potential skin permeation enhancer in transdermal patches. The Journal of Applied Research, 5(1), pp. 96-108.

Nirja, Pawan Jalwal, Jyoti Saini, Mamta dan Ritu. (2013). Formulation and Evaluation of Transdermal Drug Delivery System for Ibuprofen. International Journal of Pharmacy and Research, 4(2), pp. 162-165.

Predel, H.G., Gianetti, B., Connolly, M.P., Lewis, F. dan Bhatt, A. (2018). Efficacy and tolerability of a new ibuprofen $200 \mathrm{mg}$ plester in patients with acute sports-related traumatic blunt soft tissue injury/contusion. Postgraduate Medicine, 130 (1), pp. 24-31.

Prajapati, S.T., Patel, C.G. dan Patel, C.N. (2011). Formulation and evaluation of transdermal patch of repaglinide. International School, 1(1), pp. 1-9.

Pudyastuti, B., Nugroho, A.K. dan Martono, S. (2014). Formulasi Matriks Transdermal Pentagamavunon-0 dengan Kombinasi Polimer PVP K30 dan Hidroksipropil Metilselulosa, Jurnal Farmasi Sains Dan Komunitas, 11(2), pp. 44-49.

Puspitasari, K.D., Nurahmanto, D. dan Ameliana, L. (2016). Optimasi Hidroksipropil Metilselulosa dan Carbopol terhadap Moisture Content dan Laju Pelepasan Patch Ibuprofen In Vitro. e-Jurnal Pustaka Kesehatan, 4 (2), pp.229-234.

Rahim, F., Deviarny, C., Yenti, R. dan Ramadani, P. (2016). Formulasi Sediaan Patch Transdermal dari Rimpang Rumput Teki (Cyperus rotundus L.) untuk Pengobatan Nyeri Sendi pada Tikus Putih Jantan. Scientia, 6(1), pp. 1-6.

Rasool, B.K.A., E.F. Abu Gharbieh, S.A. Fahmy, H.S. Saad dan S.A. Khan. (2010). Development and Evaluation of Ibuprofen Transdermal Gel Formulations. Topical Journal of Pharmacy and Research, 9(4), pp. 355-363.

Rowe, R.C., Paul, J.S., dan Marian, E.Q. (2009). Handbook of Pharmaceutical Excipient Sixth Edition. Pharmaceutical Press: London.

Tranggono, R.I.F. dan Latifah. (2007). Buku Pegangan Pengetahuan Kosmetik, PT. Gramedia: Jakarta.

Valenta, C, dan Auner, B.G. (2014). The Use of Polymer for Dermal and Transdermal Delivery. European Journal of Pharmaceutics and Biopharmaceutics, 58(2), pp. 279289.

Yadav, Bhai., Mamatha., dan Prasanth. (2012). Transdermal Drug Delivery: A Technical

Writeup. Journal of Pharmaceutical Science and Innovation, 1(1), pp. 5-12.

Young dan Anne. (2002). Pratical Cosmetic Science. Mills and Bown Limited : London. 


\section{(c) (1) ()}

C 2019 by the authors. Submitted for possible open access publication under the terms and conditions of the Creative Commons Attribution-ShareAlike 4.0 International (CC BY-SA 4.0) license (https://creativecommons.org/licenses/by-sa/4.0/). 